\title{
Analysis of SIPRI's arms production data: Some suggestions for expansion
}

\section{Herbert Wulf}

Herbert Wulf is Senior Fellow at the Bonn International Center for Conversion, Bonn, Germany. He may be reached at wulf.herbert@pinnau.com.

\section{Abstract}

This article proposes that the Stockholm International Peace Research Institute's top-100 dataset of the world's largest arms producers and military service providers be expanded to permit comparison of the value of arms/service sales not only in absolute terms across countries and time but also relative to countries' industrial output. Specifically, the article suggests setting the sum of the arms/service sales of a country's top-100 members in SIPRI's list in relation to that country's output in its machinery and equipment sector. Illustrating the suggestion with data for 2015 finds that countries such as Israel, Russia, the U.K., and the U.S. have a far greater percentage of its machinery and equipment sector vested in arms production than do countries such as France, Germany, or Japan. The article also suggests comparing a country's top-arms producers to its top non-arms producers, that is, comparing country's arms-makers listed in SIPRI's top-100 list with, for example, companies in the Fortune Global 500 list. The article concludes with a discussion of methodological issues.

$\mathrm{T}$ he Stockholm International Peace Research Institute (SIPRI) first published a list of the world's one hundred largest arms producing and military service companies, by sales volume, in 1990 (SIPRI, 1990). The idea was to use the tool of company lists, common in many sectors of the economy, for the arms industry with the intention to reveal "a number of important facts about the structure of this industry" (SIPRI, 1990, p. 325). This primary purpose has not changed since. At the time, it was not possible to collect reliable data on socialist countries. Thus, SIPRI's first top-100 list included corporations of 15 countries, drawn mainly from the OECD and a few from what was then referred to as the Third World. In 2016, the last year for which data on the top-100 companies was available, the total number of countries in the list was 22 , with 40 percent of the companies located in the United States alone. Lack of data on Chinese companies was and remains a serious drawback, an information gap that should be closed whenever possible. Gauged by China's efforts in modernizing its armed forces and by anecdotal information about Chinese arms producing conglomerates, it is safe to assume that if even reasonably exact data were available, a number of Chinese companies would have to be included in the top-100 list.

The main information contained in SIPRI's arms industry data collection concerns companies' arms sales, that is, revenue, and their associated rankings. (Technically, this is arms and military service sales but, for the sake of brevity, is shortened here to "arms" sales.) This is complemented by arms sales as a percentage of a company's total sales -indicating companies' revenue dependence on arms sales - as well as by information on companies' employment and profit levels. ${ }^{1}$
Among the best-known of SIPRI's research products, the list probably is also the best available global collection.

As the list is published annually, an analysis of temporal trends and geographic distribution of the major arms producing companies is possible. The suggestion made in this article is not to change this centerpiece of information but to add other indicators. As has been pointed out in numerous publications, a comprehensible database on arms production is not available. Data on arms production volume is scarce, usually addressing firms or occasionally countries (e.g., arms procurement in NATO countries as a proxy for arms production). Beyond the SIPRI list, no global statistics exist, neither as industry statistics (since arms production is not a recognized branch in international statistics) nor as econometric data (input-output tables) or as UN statistics.

My proposal for a modest expansion of the SIPRI database relates to non-arms economic and industrial indicators so as to assess the size of a country's arms sector relative to its nonarms sector. This is analogous to what SIPRI already does in regard to countries' military expenditure data, namely recording it in absolute terms as well as relative to central government spending and relative to GDP. Comparing arms sales with non-arms economic and industrial indicators can illustrate if the arms industry in a given country is a key industry or plays a less important role. In this vein, I suggest two indicators: First, the arms sales ratio to industrial output of the machinery and equipment sector and, second, the rank of the SIPRI top-100 companies within the Fortune Global 500 companies (and in the top company list of certain countries). 
Table 1: Share of arms (and military service) sales to output in machinery and equipment, 2015

$\begin{array}{lccc} & (1) & (2) & (3) \\ \text { Israel } & 7,710 & 4,955 & 156 \\ \text { Russia } & 27,100 & 26,876 & 101 \\ \text { UK } & 40,700 & 72,511 & 56 \\ \text { USA } & 213,530 & 466,288 & 46 \\ \text { France } & 18,740 & 83,350 & 22 \\ \text { Ukraine } & 870 & 4,020 & 22 \\ \text { India } & 5,570 & 44,267 & 13 \\ \text { Sweden } & 2,640 & 28,768 & 9 \\ \text { Turkey } & 1,890 & 21,696 & 9 \\ \text { Italy } & 10,800 & 144,503 & 7 \\ \text { South Korea } & 6,390 & 89,427 & 7 \\ \text { Singapore } & 1,660 & 22,854 & 7 \\ \text { Australia } & 890 & 13,221 & 7 \\ \text { Poland } & 1,190 & 19,461 & 6 \\ \text { Switzerland } & 1,690 & 34,176 & 5 \\ \text { Norway } & 730 & 17,892 & 4 \\ \text { Japan } & 7,290 & 272,331 & 3 \\ \text { Spain } & 740 & 27,600 & 3 \\ \text { Germany } & 5,600 & 307,737 & 2 \\ \text { Brazil } & 810 & 44,136 & 2 \\ \text { Canada } & 760 & 36,330 & 2\end{array}$

Notes: Column (1) — arms sales of SIPRI top-100 companies (in millions of USD)*; (2) output of the machinery and equipment sector (in millions of USD)**; (3) share of arms sales to output (\%).

Sources: * SIPRI (2015); ** UNIDO (2017). UNIDO statistics refer to the output of industrial establishments and cover sectors such as mining, manufacturing, electricity, gas, steam, and air-conditioning.

\section{Arms sales ratio to industrial output}

While SIPRI's top-100 list is informative in its own right, adding comparative indicators can help reveal the relative importance of a given country's arms production sector within industry and to the economy at large. A comparison to the machinery and equipment sector would seem especially appropriate as this sector develops and produces technically significant products, comparable to technical requirements in arms production.

For the year 2015, Table 1 compares SIPRI's top-100 list with output for machinery and equipment by country. Column 1 shows the sum total of companies' arms sales in each country and compares this to the respective countries' industrial output in column 2. For example, in the United States, arms sales of
This article proposes that SIPRI's top-100 list of the world's largest arms producers be expanded to permit comparison of the value of arms sales not only in absolute terms but also relative to industrial output and to a country's GDP.

companies in SIPRI's top-100 list totaled USD213.5 billion. This compares to USD466.3 billion of industrial output that year, or almost half as shown in column 3. Even though its manufacturing and equipment sector is the largest in the world, the arms sales of just the biggest of the U.S. arms companies occupy a very large part of the U.S. industrial sector, namely 46 percent. In the case of United Kingdom, the size of its largest arms companies is even more important-at 56 percent - in comparison to its machinery and equipment sector. In contrast, Japan's largest arms producers account for only three percent of its machinery and equipment sector. Similarly, in Germany the percentage is only two percent.

A methodological remark is in order here. The comparison of arms sales of companies to the output of an entire sector is, of course, problematic since sales and sectoral output are different types of indicators. To generate profits, the value of sales, i.e., revenues, must cover all required inputs into the production of arms products while sectoral output is based on the concept of value added only (that is, over and above input costs). This becomes clear by looking at the case of Israel which, in Table 1, shows a share of 156 percent. Moreover, the tabular comparison suggests that arms production is part of the machinery and equipment sector. However, this is not always the case. Particularly in Israel, military service contracts play a big role in the sales of the defense sector which, according to SIPRI's definition, are part of "arms" sales. Further, SIPRI's list does not include all of a countries' arms manufacturing activity but only that portion that results in a top-100 listing. As such, the percentages given in column 3 are lower-bound minima. Despite these methodological cautions, the purpose here-of indicating the arms sector's minimum relative economic importance-would seem valid. Alternative comparisons could be made, for instance, to a country's motor vehicles or any other industry.

Table 1 is sorted by column 3, that is, in order of how important is the arms sector to an economy. This ranges from 156 percent in Israel, to 56 in the U.K. and 46 in the U.S. to Germany, Brazil, and Canada at the bottom of the table with only two or three percent. Accordingly, the arms sector is of great importance relative to the machinery and equipment sector in Israel, the U.K., and the U.S. and of comparatively little importance in Germany, Brazil, and Canada. 
Table 2: Top-10 SIPRI arms producers in the Fortune Global 500 list, 2015

$\begin{array}{lccccc}\text { Company } & \begin{array}{c}\text { FG500 } \\ \text { rank }\end{array} & \begin{array}{c}\text { SIPRI } \\ \text { rank }\end{array} & \begin{array}{c}\text { Total sales } \\ \text { (USD mn) }\end{array} & \begin{array}{c}\text { Arms sales } \\ \text { (USD mn) }\end{array} & \begin{array}{c}\% \text { arms } \\ \text { sales }\end{array} \\ \text { Walmart } & 1 & - & 482,130 & - & - \\ \text { Boeing } & 85 & 2 & 96,114 & 27,960 & 29 \\ \text { Airbus Group } & 106 & 7 & 71,476 & 12,860 & 18 \\ \text { United Technologies } & 149 & 8 & 61,047 & 9,500 & 16 \\ \text { Lockheed Martin } & 237 & 1 & 46,132 & 36,440 & 79 \\ \text { General Dynamics } & 386 & 6 & 31,469 & 19,240 & 61 \\ \text { BAE Systems } & 468 & 3 & 25,647 & 25,510 & 99 \\ \text { Northrop Grumman } & 494 & 5 & 23,256 & 20,060 & 86 \\ \text { Wuhan Iron \& Steel } & 500 & - & 23,720 & - & - \\ \text { Raytheon } & - & 4 & 23,247 & 21,780 & 94 \\ \text { Finmeccanica } & - & 9 & 14,412 & 9,300 & 65 \\ \text { L-3 Communications } & - & 10 & 10,406 & 8,770 & 93\end{array}$

Sources: SIPRI (2015); Fortune Global 500

https://de.wikipedia.org/wiki/Fortune Global 500\#2015

Ranking of arms and non-arms producing companies The "blueprint" idea for SIPRI's original listing of the world's largest arms producing companies came from existing annual rankings of corporations such as the Fortune 500 list. Why, then, not also directly compare SIPRI's list with Fortune's global or other country-specific lists? Assume for instance that SIPRI wishes to analyze Russia's arms producing sector in a given year in more detail. It could use an all-Russia industrial ranking list as a way to assess the role the arms producing companies play within Russia.

Fortune does not differentiate between arms and non-arms production in a given company, simply using total sales as the indicator for inclusion in its list. For 2015, only seven arms-producing companies appear in the Fortune Global 500 list (see Table 2), and four of them only because of their high total sales. The other three-Lockheed Martin, Boeing, and BAE Systems - would qualify by arms sales alone, however. The smallest of the Fortune Global 500, China's Wuhan Iron \& Steel, has total sales slightly larger than Raytheon, which ranks fourth in SIPRI top-100 list for 2015. Put differently, SIPRI's largest arms producing companies are small relative to other big corporations. The largest company in the Fortune Global 500 list (Walmart) is ten times bigger by sales than is the largest arms-producing company in SIPRI's list (Lockheed Martin).

Using company lists for specific countries, or regions, one could make similar, more detailed analyses. For example, in the European Union BAE Systems, the largest European arms- maker, appears only at rank 125 . No other arms-producing company ranks among the top150 European companies. Unsurprisingly, Japanese arms producing firms are not in the same league as the big technology companies in the country. In Russia, the largest arms company, United Aircraft Corporation, is listed at rank 25. None of SIPRI's top Indian arms companies ranks among the top-50 companies in that country. ${ }^{2}$

As a general result, for most countries it can be stated that in quantitative terms arms producing firms do not play an overwhelmingly important role. Often the sector is marginal compared to the rest of the economy. However, in a few cases, like Israel, the U.K., and the U.S., the arms industry is a relatively important producing sector.

\section{Conclusion}

As mentioned, in making comparisons certain methodological constraints need to be observed (and readers should be made aware of the methodological limitation). I point to four such constraints.

First, I have chosen UNIDO statistics for the output of the machinery and equipment sector. There are, of course, other industry statistics available. It is essential to choose a dataset that allows comparisons to the SIPRI top-100 type of data. The arms industry should be classified as belonging to the machinery and equipment sector. However, as noted, in Israel the arms industry is, according to SIPRI statistics, bigger than the entire machinery and equipment sectors as defined by UNIDO.

Second, sales (revenue) and output (value-added) are not the same thing. It is necessary to study the methodology used in detail and possibly opt for other, more appropriate indicators. Third, the cutoff point for SIPRI's top-100 arms producing companies results in a high concentration for U.S.based companies. If the list were expanded to the, say, top-150 or top-200 companies, the ratio of arms sales to machinery and equipment output (in Table 1) would probably be more informative. Since SIPRI collects data on many more than the top-100 companies, it would be worthwhile to consider 
expanding the table beyond the top-100 firms (without necessarily publishing this expanded list regularly). And fourth, using companies' arms sales as representing arms production of the whole of a country is, of course, misleading. Companies listed among SIPRI's top-100 do not necessarily comprise the whole of a country's arms production sector. The fluctuations in SIPRI's list (especially at the bottom of the list) are considerable and this may distort the overall picture. If, for example, two arms companies merge they might, due to the merger, make it into SIPRI's list and, as a result, other companies, possibly from other countries, might fall out of the list. This is not a specific problem regarding the arms industry but is a general methodological problem for all company ranking lists.

Despite methodological difficulties (which are commonplace in economic and econometric studies), it is suggested here to expand the SIPRI database and, especially, its analysis of its top-100 list by two additional indicators: First, comparing the arms sales of the major arms producers with other (non-military) industrial and economic indicators and, second, ranking the SIPRI top-100 companies with other global, regional, or country company lists. This modest expansion allows for a broader analysis of the economic importance of the arms industry.

Notes

For comments I thank participants at the SIPRI arms industry workshop held in March 2018 in Stockholm and an anonymous reviewer.

1. SIPRI's list is available at https://www.sipri.org/databases /armsindustry.

2. EU: See https://en.wikipedia.org/wiki/List_of_largest European_companies_by_revenue. Russia: See https://en. wikipedia.org/wiki/List_of_companies_of_Russia\#Largest_f irms.

\section{References}

[SIPRI] Stockholm International Peace Research Institute. 1990. SIPRI Yearbook. Oxford, UK: Oxford University Press.

[UNIDO] United Nations Industrial Development Organisation. 2017. INDSTAT 2. ISIC Revision 3. 